\title{
Pengaruh jenis inokulum Aspergillus niger, Saccharomyces cereviseae dan lama fermentasi terhadap komposisi nutrisi ampas Putak (Corypha gebanga)
}

\section{Influence of inoculum type Aspergillus niger, Saccharomyces cereviseae and old fermentation toward nutrients composition of Putak (Corypha gebanga) Waste}

\author{
Daniel Soares*, Irfan H. Djunaidi, dan Muhammad Halim Natsir \\ Minat Nutrisi dan Makanan Ternak Fakultas Peternakan Program Studi Magister Ilmu Ternak \\ Universitas Brawijaya, Malang.
}

Submitted : 28 November 2017, Accepted : 10 March 2018

\begin{abstract}
ABSTRAK: Penelitian bertujuan untuk mengevaluasi komposisi nutrien ampas putak terfermentasi oleh Aspergillus niger, Saccharomyces cereviseae dan kombinasinya. Metode penelitian yang digunakan adalah percobaan laboratorium dengan rancangan acak lengkap pola tersarang. Faktor pertama, jenis inokulum (P): Aspergillus niger, Saccharomyces cereviseae dan kombinasi dengan level 1,5\% dan lama inkubasi (W): 0, 24, 48 dan 72 jam sebagai faktor kedua. Parameter yang diukur pada ampas putak adalah analisiskomponen serat. Hasil penelitian menunjukkan jenis inokulum berpengaruh terhadap komponen serat (Neutral Detergent Fiber/NDF, Hemiselulosa dan Lignin) adalah berbeda sangat nyata $(\mathrm{P}<0,01)$ dan komponen serat (Acid Detergent Fiber/ADF dan Selulosa) berbeda nyata $(\mathrm{P}<0,05)$ sedangkan lama inkubasi menunjukkan berbeda sangat nyata $(\mathrm{P}<0,01)$ terhadap komponen serat $(\mathrm{NDF})$ dan tidak berbeda nyata $(\mathrm{P}>0,05)$ terhadap $\mathrm{ADF}$, hemiselulosa, selulosa dan lignin.
\end{abstract}

Kata kunci: Ampas Putak, Aspergillus niger dan Saccharomyces cereviseae

ABSTRACT: The experiment was to evaluate the nutrient composition of fermented Putak waste by Aspergillus niger, Saccharomyces cereviseae and its combinations. The experiment method used laboratory experimental method by applying Nested Plot Random Design. The first factor is inoculum (P): Aspergillus niger, Saccharomyces cereviseae and their combination on the level of 1,5\% and the incubation time length (W): $0,24,48,72$ hours as the second factor. Variables measured of putak waste fiber component analysis. The results showed that the type of inoculum effect on fiber component (Neutral Detergent Fiber / NDF, Hemicellulose and Lignin) is very significantly influence $(\mathrm{P}<0,01)$ and fiber component (Acid Detergent Fiber/ADF and Cellulose) is significantly influence $(\mathrm{P}<0,05)$, while the incubation time showed very significantly influence $(\mathrm{P}<0,01)$ to the fiber component (NDF) and not significantly influence $(\mathrm{P}>0,05)$ to $\mathrm{ADF}$, hemicellulose, cellulose and lignin.

Keywords: Putak waste, Aspergllus niger and Saccharomyces cerevisiae.

\footnotetext{
*Corresponden author: denilton.169@gmail.com
} 


\section{PENDAHULUAN}

Ampas putak adalah produk samping dari putak yang di hasilkan dari isi batang Gewang (Corypha gebanga). Putak selama ini digunakan sebagai pangan oleh masyarakat wilayah selatan Timor Leste. Ampas putak dihasilkan dari proses pembuatan putak memiliki potensi besar karena banyak tersedia di wilayah selatan Timor Leste. Peternak Timor Leste saat ini belum menggunakan ampas putak sebagai bahan pakan unggas karena kandungan nutrisi nya khususnya kadar serat yang tinggi.

Pohon gewang (Corypha gebanga) tumbuh subur didaerah Timor Leste dan Pulau Timor. Putak merupakan pakan alternative sumber energi potensial yang ada di Timor Leste dengan ketersediaan tinggi di daerah-daerah penghasil putak. Satu pohon gewang dapat menghasilkan rata - rata $660 \mathrm{~kg}$ putak segar dengan bahan kering cukup tinggi yaitu 45\% - 50\%, kandungan serat kasar 12,04\%, energi 4210 kkal, dan protein kasar 2,53\% (Nulik et al., 1988).

Ketersediaan ampas putak sebagai hasil samping pengambilan pati tepung putak berpotensi digunakan sebagai bahan pakan sumber energi. Penyusunan pakan ternak berbasis ampas putak sangat diharapkan sebagai salah satu bahan dasar yang dapat memenuhi kebutuhan ternak. Khususnya, sebagai bahan pakan sumber energi potensial untuk alternatif pengganti jagung pada daerah penghasil putak dan ketersediaan jagung yang terbatas.

Kendala pemanfaatan ampas putak adalah kandungan protein kasar rendah dan serat kasarnya tinggi, sehingga perlu pengolahan untuk meningkatkan kualitas nutrisinya. Teknologi aplikatif yang dapat diterapkan adalah fermentasi dengan memanfaatkan aktivitas mikroba.
Fermentasi dengan menggunakan Aspergillus niger dilakukan pada tepung putak menunjukkan terjadi peningkatan protein kasar putak fermentasi 3,25 vs 12,53\% (Hilakore, 2008). Penelitian lain yang menggunakan Saccharomyces cereviseae juga dapat meningkatkan kandungan protein (Oboh, 2006).

$$
\text { Penelitian bertujuan untuk }
$$

mengevaluasi komposisi nutrien ampas putak terfermentasi oleh Aspergillus niger, Saccharomyces cereviseae dan kombinasinya.

\section{MATERI DAN METODE}

Penelitian ini dilaksanakan di Laboratorium Nutrisi dan Makanan Ternak Fakultas Peternakan Universitas Brawijaya Malang selama Mei 2017. Metode yang digunakan adalah percobaan laboratorium dengan menggunakan Rancangan Acak Lengkap (RAL) pola tersarang dengan jenis inokulum Aspergillus niger(P1), Saccharomyces cereviseae $(\mathrm{P} 2)$ dan kombinasinya (P3) sebagai faktor pertama (P) dengan level 1,5\% dan lama inkubasi 24 (W1), 48 (W2) dan 72 jam (W3) sebagai faktor kedua (W). Setiap perlakuan diulang tiga kali. Peubah yang diukur adalah komponen serat (Neutral Detergent Fiber/NDF, Acid Detergent Fiber/ADF, Hemiselulosa, Selulosa dan Lignin) berdasarkan metode Analisis Van Soest (1994). Data yang diperoleh diolah dengan analisis sidik ragam (Anova), dan uji Duncan.

\section{Prosedur penelitian fermentasi}

Ampas putak $100 \mathrm{~g}$ kering direndam ke dalam air dengan lama waktu 30 menit, kemudian ditiriskan lalu dikemas dalam plastik yang tahan panas. Mineral $\mathrm{KH}_{2} \mathrm{PO}_{4}$ $1 \mathrm{~g},\left(\mathrm{NH}_{4}\right)_{2} \mathrm{SO}_{4} 2 \mathrm{~g}$ dan urea $3 \mathrm{~g}$ dicampur dalam air aquades $100 \mathrm{ml}$ berikutnya 
ditambahkan pada ampas putak lalu dikukus dalam waktu 30 menit. Waktu kukusnya selesai lalu di dinginkan kemudian ditambahkan inokulum yang disediakan sesuai dengan perlakuan, seterusnya diinkubasi sesuai waktu perlakuan, lalu dikeringkan kemudian di giling untuk dilakukan analisis.

\section{HASIL DAN PEMBAHASAN}

Pengaruh perlakuan inokulum terhadap hasil analisis komponen serat

Rata-rata kandungan komponen serat kasar (NDF, ADF, Hemiselulosa, Selulosa dan Lignin) ampas putakdengan inokulum berbeda dapat dilihat pada tabel 1.

Tabel 1. Pengaruh Jenis Inokulum Fermentasi Terhadap Komponen Serat Ampas Putak (\%)

\begin{tabular}{cccc}
\hline \multirow{2}{*}{ Komponen Serat } & \multicolumn{3}{c}{ Perlakuan } \\
\cline { 2 - 4 } & P1 & P2 & P3 \\
\hline NDF & $56,78 \pm 9,20^{\mathrm{C}}$ & $49,68 \pm 9,08^{\mathrm{B}}$ & $44,31 \pm 4,01^{\mathrm{A}}$ \\
ADF & $17,55 \pm 3,49^{\mathrm{b}}$ & $15,52 \pm 3,25^{\mathrm{a}}$ & $14,10 \pm 1,08^{\mathrm{a}}$ \\
Hemiselulosa & $39,23 \pm 8,26^{\mathrm{C}}$ & $34,16 \pm 6,51^{\mathrm{B}}$ & $30,20 \pm 4,56^{\mathrm{A}}$ \\
Selulosa & $12,61 \pm 4,51^{\mathrm{b}}$ & $12,19 \pm 3,84^{\mathrm{b}}$ & $8,94 \pm 1,82^{\mathrm{a}}$ \\
Lignin & $4,13 \pm 1,43^{\mathrm{B}}$ & $2,23 \pm 0,97^{\mathrm{A}}$ & $3,64 \pm 0,89^{\mathrm{B}}$ \\
\hline
\end{tabular}

Keterangan: superskrip huruf kapital dan huruf kecil yang berbeda pada baris yang sama menunjukkan perbedaan sangat nyata $(\mathrm{P}<0,01)$ dan perbedaan nyata $(\mathrm{P}<0,05)$

Komponen serat merupakan bagian serat yang berasal dari tanaman yang memiliki ikatan kompleks dan merupakan bagian dari karbohidrat, oleh sebab itu perlu dilakukan perombakan melalui fermentasi untuk merubah senyawa-senyawa kompleks menjadi yang sederhana. NDF mewakili kandungan dinding sel yang mengandung selulosa, hemiselulosa, lignin dan protein (Praptiwi, 2011).

Penurunan komponen serat pada ampas putak hasil analisis statistik menunjukkan perbedaan yang sangat nyata $(\mathrm{P}<0,01)$ terhadap NDF, Hemiselulosa dan Lignin dan berbeda nyata $(\mathrm{P} 0<05)$ terhadap ADF dan Selulosa. Hal ini diduga Aspergillus niger menghasilkan enzim selulase, dan Saccharomycescereviseae menghasilkan enzim selulase dan enzim ligninase.Hal ini sesuai dengan hasil yang dilaporkan oleh Yopi dkk (2006) bahwa Saccharomyces cereviseae mampu menghasilkan enzim ligninase yang terdapat pada bahan kapuk. Namun dilihat secara keseluruhan terjadi penurunan pada semua komponen serat khususnya kombinasi kedua inokulum (P3), hal ini diduga kerja mikroba yang dihasilkan kedua inokulum sangat efektif.

Kandungan serat pada ampas putak yang difermentasi oleh kombinasi Aspergillus niger, Saccharomyces cereviseae (P3) menunjukkan adanya penurunan pada NDF $(44,31 \%)$, ADF $(14,10 \%)$, Hemiselulosa $(30,20 \%)$ dan selulosa $(8,94 \%)$. Perlakuan fermentasi Saccharomyces cereviseae (P2) menunjukkan penurunan lignin terendah (2,23\%) dan perlakuan Aspergillus niger(P1) menunjukkan persentase lignin tertinggi yaitu $(4,13 \%)$. Hal ini dipengaruhi oleh enzim selulase dan enzim ligninase yang dihasilkan dari inokulum Aspergillus niger dan Saccharomyces cereviseae mampu merombak ikatan-ikatan kompleks dari serat menjadi komponen yang lebih sederhana. Hasil dari penelitian ini persentase NDF, ADF, Selulosa dan Lignin nilainya lebih kecil dari hasil penelitian Londok dan Mandey (2014) pada daun 
sirsak yaitu NDF (53,96\%), ADF (49,61\%), Selulosa $(34,71 \%)$ dan Lignin $(14,64 \%)$. Penelitian Yohanista, Osfar, dan Eko (2014) dengan menggunakan Aspergillus nigerdan Rizhopus oligosporuspada pakan onggok dan ampas tahu dapat menurunkan fraksi serat ADF menjadi 33,38\% sedangkan hasil penelitian Jati dkk (2017) memperoleh kandungan ADF ransum pakan pellet unggas ditambahkan biomassa indigofera zollingeriana lebih kecil yaitu $9,42 \%-14,40 \%$.

\section{Pengaruh perlakuan waktu terhadap hasil analisis komponen serat}

Pengaruh perlakuan waktu fermentasi pada ampas putak berpengaruh sangat nyata $(\mathrm{P}<0,01)$ terhadap NDF dan berpengaruh tidak nyata $(\mathrm{P}>0,05)$ terhadap ADF, Hemiselulosa, Selulosa dan Lignin). Kandungan NDF yang paling rendah terjadi pada P2W3 (41,37\%), hal ini menunjukkanSaccharomyces cereviseae sangat efektif dalam menurunkan NDF dalam waktu 72 jam.Lama waktu fermentasi tidak berpengaruh signifikan terhadappenurunan ADF. Kelompok Aspergillus niger menghasilkan penurunan
ADF terendah pada waktu fermentasi 42 jam (P1W2), sedangkan kelompok Saccharomyces cereviseae menghasilkan penurunan $\mathrm{ADF}$ terendah pada waktu fermentasi 72 jam (P2W3). Penurunan ADF terendah dan tercepat terjadi pada kombinasi Aspergillus niger, Saccharomyces cereviseae pada waktu fermentasi 24 jam (P3W1) sebesar $13,10 \%)$.

Pengaruh waktu terhadap komponen serat ampas putak pada tabel 2, menunjukkan bahwaSetiap jenis inokulum memiliki waktu optimum untuk menurunkan $\mathrm{ADF}$ dan tidak selalu terjadi penurunan kandungan ADF, namun menurut Musnandar (2006) penurunan ADF oleh mikroba sejalan dengan pertumbuhan miselium dan produksi enzim dan waktu untuk memasuki jaringan serat. Musnandar (2006) menjelaskan lebih lanjut bahwa meningkatnya konsentrasi $\mathrm{CO}_{2}$ dan asam-asam dapat menghambat pertumbuhan jamur aerob sehingga degradasi ADF juga menjadi lambat. Ratarata perlakuan waktu terhadap komponen serat tersaji pada Tabel 2.

Tabel 2. Pengaruh lama waktu inkubasi terhadap komponen serat Ampas Putak (\%)

\begin{tabular}{ccccccc}
\hline \multirow{2}{*}{ Perlakuan } & & \multicolumn{5}{c}{ Komponen Serat } \\
\cline { 2 - 7 } & & NDF & ADF & Hemiselulosa & Selulosa & Lignin \\
\hline \multirow{2}{*}{ P1 } & W1 & $65,09 \pm 5,58^{\mathrm{b}}$ & $19,74 \pm 5,71$ & $45,36 \pm 0,12$ & $14,89 \pm 7,42$ & $3,98 \pm 1,40$ \\
& W2 & $51,89 \pm 3,43^{\mathrm{a}}$ & $15,79 \pm 1,06$ & $36,10 \pm 2,36$ & $9,98 \pm 1,78$ & $4,99 \pm 2,08$ \\
& W3 & $53,35 \pm 11,77^{\mathrm{a}}$ & $17,13 \pm 1,75$ & $36,22 \pm 13,52$ & $12,97 \pm 2,22$ & $3,42 \pm 0,14$ \\
\cline { 2 - 7 } P2 & W1 & $60,49 \pm 4,13^{\mathrm{b}}$ & $18,62 \pm 4,30$ & $41,87 \pm 0,17$ & $16,11 \pm 4,90$ & $2,01 \pm 0,64$ \\
& W2 & $47,18 \pm 0,78^{\mathrm{a}}$ & $14,21 \pm 0,52$ & $32,97 \pm 1,30$ & $10,46 \pm 0,51$ & $2,36 \pm 0,50$ \\
& W3 & $41,37 \pm 4,88^{\mathrm{a}}$ & $13,75 \pm 1,37$ & $27,62 \pm 3,51$ & $10,01 \pm 0,16$ & $2,32 \pm 1,73$ \\
\cline { 2 - 7 } & W1 & $43,89 \pm 1.67^{\mathrm{a}}$ & $13,10 \pm 0,78$ & $30,79 \pm 0,89$ & $9,82 \pm 0,90$ & $2,70 \pm 0,22$ \\
P3 & W2 & $42,83 \pm 5,34^{\mathrm{a}}$ & $14,79 \pm 0,48$ & $28,04 \pm 5,82$ & $6,64 \pm 0,16$ & $4,65 \pm 0,13$ \\
& W3 & $46,21 \pm 4,92^{\mathrm{a}}$ & $14,43 \pm 1,20$ & $31,78 \pm 6,12$ & $10,37 \pm 0,54$ & $3,56 \pm 0,49$ \\
\hline
\end{tabular}

Keterangan:superskrip yang berbeda pada kolom yang sama menunjukkan berbeda sangat nyata $(\mathrm{P}<0,01)$ 
Perlakuan waktu tidak memberikan perbedaan signifikan terhadap kandungan hemiselulosa. Kandungan hemiselulosa terendah terdapatpada P2W3 $(27,62 \%)$ hal ini disebabkan Saccharomyces cereviseae dapat bekerja dengan optimum dan waktu fermentasi selama 72 jam (W3) mengakibatkan Saccharomyces cereviseaedapat dapat masuk lebih jauh ke jaringan putak, sehingga pertumbuhannya lebih luas.Waktu fermentasi dan jumlah inokulum yang cukup menurut Musnandar (2006) akan meningkatkan kecepatan miselium untuk menutupi substrat, sehingga menghasilakan enzim pengurai hemiselulosa lebih banyak, oleh karena itu kandungan hemiselulosa dapat menurun.

Nilai selulosaterendah terdapat pada P3W2 (6,64\%), kombinasi inokulum Aspergillus niger, Saccharomyces cereviseaeyang menghasilkan enzim selulase dapat bekerja secara optimal untuk merombak selulosa pada ampas putak menjadi ikatan yang sederhana, hal ini sejalan dengan Musnandar (2006) yang menyatakan bahwa enzim selulase terdiri dari komplek eksoglukanase, endoglukanase dan $\beta$-glukosidase yang merubah selulosa jadi glukosa untuk pertumbuhan jamur sebagai sumber karbon.

$$
\text { Berdasarkan Tabel 2, }
$$

diketahuirataan kandungan lignin terendah pada P2W1 (2,01\%), hasil ini lebih rendah dari hasil yang didapatkan Musnandar (2006) yang menggunakan sabut sawit, yaitu 9,933\%. Menurunnya lignin pada P2W1 diduga karena Saccharomyces cereviseae dapat menghasilkan enzim ligninase yang berfungsi untuk merombak struktur lignin yang ada dalam karbohidrat. Hal ini sesuai dengan pendapat Londok dan Mandey (2014) yang menjelaskan bahwa lignin tidak tergolong dalam karbohidrat tetapi berada dalam tanaman dan merupakan komponen atau kesatuan dalam karbohidrat. Serat kasar sebagai bagian penting yang perlu diperhatikan dari segi nutrisi karena lignin selalu berasosiasi dengan selulosa dan hemiselulosa.

Kandungan serat pada pakan yang dibutuhkan oleh beberapa jenis unggas yang berbeda-beda seperti puyuh maksimal $7 \%$, itik $8 \%$ sedangkan ayam pedaging maksimal 6\% (Has dkk, 2014). Tossaporn (2013) menjelaskan unggas khususnya broiler memiliki kemampuan yang rendah untuk memanfaatkan serat kasar namun tetap membutuhkan serat kasar dalam jumlah kecil dan dapat mempengaruhi histologi saluran pencernaan.

\section{KESIMPULAN}

Hasil penelitian dari fermentasi terbaik diperoleh pada perlakuan kombinasi antara Aspergillus niger dan Saccharomyces cereviseae (P3) yaitu dapat menurunkan komponen serat (NDF, ADF, Hemiselulosa, Selulosa dan Lignin) dan perlakuan waktu dapat berpengaruh terhadap NDF dengan sangat nyata. Jenis inokulum Aspergillus niger dan Saccharomyces cereviseae dapat menurunkan komponen serat ampas putak.

\section{DAFTAR PUSTAKA}

Has H, A. Napirah dan A. Indi. 2014. Efek peningkatan serat kasar dengan penggunaan daun murbei dalam ransum broiler terhadap persentase bobot saluran ppencernaan. Fakultas Peternakan Universitas Halu Oleo Kendari. JITRO. 1(1).

Hilakore, M. A. 2008. Peningkatan kualitas nutritsi putak melalui fermentasi campuran Trichoderma reesei dan Aspergillus niger sebagai pakan ruminansia. Disertasi Pasca Sarjana IPB. Bogor. 
Jati. P.Z, T. Adelina dan D.A. Mucra. 2017. Kandungan fraksi serat ransum pellet unggas dengan penggunaan tepung indigofera zollingeriana. Fakultas pertanian dan peternakan Universitas Islam Negeri Sultan Syarif Kasim Rau. Jurnal peternakan 14 (1), 11-17.

Londok J. J. M. R dan J. S. Mandey. 2014. Potensi fitokimia dan aktivitas antimikroba daun sirsak (Annona muricata linn.) sebagai kandidat bahan pakan ayam pedaging. Jurnal LPPM Bidang Sains dan Teknologi. 1 (1).

Musnandar E. 2006. Pengaruh Dosis Inokulum Marasmius sp. dan Inkubasi terhadap Kandungan Komponen Serat dan Protein Murni pada Sabut Kelapa Sawit untuk Bahan Pakan Ternak. Jurnal Ilmiah IlmuIlmu Peternakan. 9(4).

Nulik, J., P. Th. Fernandez dan A. Bamualim. 1988.Pemanfaatan dan ProduksiPutak Sebagai Sumber Energi Makanan Ternak Sapi dan Kambing. Laporan Penelitian Komponen Teknologi Peternakan, Main Base Kupang1987-1988. Proyek NTASP. BPPP Deptan.

Oboh, G. 2006. Nutrient enrichment of cassava peels using a mixed culture of Saccharomyces cerevisiae and Lactobacillus spp. Solid media fermentation techniques. Biotechnology 9(1), 46-48.

Praptiwi I. I. 2011. Analisis kandungan ADF dan NDF limbah tiga varietas tanaman sorgum (Sorghum bicolor Moench) sebagai sumber pakan untuk ternak ruminansia. Jurnal Agricola.1(2).
Tossaporn Incharoen. 2013. Histological adaptations of the gastrointestinal tract of broilers fed diets containing insoluble fiber from rice hull meal. American Journal of Animal and Veterinary Sciences, 8(2), 79-88.

Van Soest, J. P. 1994. Nutritional Ecology of the Ruminant. $2^{\text {nd }}$ ed. Cornell University Press.

Yohanista, M. Osfar S. dan Eko W. 2014. Evaluasi nutrisi campuran onggok dan ampas tahu terfermentasi Aspergilus niger, Rizhopus oligosporus dan kombinasi bahan pakan pengganti tepung jagung. Jurnal Ilmu-Ilmu Peternakan. 24(2), 72-83.

Yopi, A. Purnawan, A. Thontowi, H. Hermansyah, A. Wijanarko. 2006. Preparasi mannan dan mannanase kasar dari bungkil kelapa sawit. Jurnal Teknologi, 20(4), 312-319. 